Jpn. J. Med. Sci. Biol., 47, 167 - 178, 1994.

\title{
PHYLOGENETIC COMPARISON BETWEEN ARCHETYPAL AND DISEASE-ASSOCIATED JC VIRUS ISOLATES IN JAPAN
}

\author{
Kenzo KATO, Jing GUO1, Fumiaki TAGUCHI2, Osami DAIMARU3, \\ Masako TAЛMA4, Hideyuki HAIBARA5, Juzo MATSUDA6, \\ Morito SUMIYA7 and Yoshiaki YOGO1
}

Department of Virology II, National Institute of Health, 1-23-1 Toyama, Shinjukuku, Tokyo 162, 1Department of Viral Infection, the Institute of Medical Science, University of Tokyo, 4-6-1 Shirokanedai, Minato-ku, Tokyo 108, 2Department of Microbiology, School of Allied Health Sciences, Kitasato University, Sagamihara, Kanagawa 228, 3the Second Department of Internal Medicine, Aichi Medical University, Nagakute-cho, Aichi-gun, Aichi 480-11, 4 Central Clinical Laboratory, 5 the Second Department of Pathology, and 6the First Department of Internal Medicine, Teikyo University of Medicine, 2-11-1 Kaga, Itabashi-ku, Tokyo 173 and 7Division of Rheumatology, International Medical Center of Japan, Toyama, Shinjuku-ku, Tokyo 162

(Received June 10, 1994. Accepted July 11, 1994)

SUMMARY: We examined the phylogenetical correlation between two types of JC virus (JCV) isolates, archetypes derived from the urine of nonimmunocompromised individuals and PML-types derived from the brain of patients with progressive multifocal leukoencephalopathy (PML) in Japan. A phylogenetic tree was constructed for eight JCV isolates, five PML-types obtained in this and previous studies and three representative archetypes, from DNA sequence data on the VP1 (major capsid protein) gene. The eight isolates were divided into two major groups, named subtypes MY and CY after the representative archetypal isolates. Four of five PML-type isolates belonged to subtype MY, and the other one to

加藤賢三(国立予防衛生研究所ウイルス且部)

余郷嘉明·郭 鏡 (東京大学医科学研究所ウイルス感染研究部 港区白金台4-6-1)

田口文章(北里大学医療衛生学部微生物学研究室 相模原市北里1-15-1)

大圓修身(愛知医科大学第二内科学教室 愛知県愛知郡長久手町大字岩作字雁又 21)

田島マサ子(帝京大学医学部中検ウイルス部 板橋区加賀2-11-1)

南風原英之(帝京大学医学部第二病理学教室 板橋区加賀 2-11-1)

松田重三(帝京大学医学部第一内科学教室 板橋区加賀2-11-1)

隅谷護人(国際医療センター膠原病科 新宿区戸山1-21-1) 
subtype CY. Isolates belonging to subtype MY were further divided into two groups; one group containing archetype MY and three PML-types and the other one containing archetype YI and a PML-type. These findings, together with those in our previous study that correlated various JCV isolates in the world provide evidence for the hypothesis that JCVs associated with PML may have been generated from archetypal JCVs persisting in the patients.

\section{INTRODUCTION}

JCV is widespread in the human population (1). While it is not clear whether this virus is associated with any disease in the general population, it causes a fatal demyelinating disease of the central nervous system, progressive multifocal leukoencephalopathy (PML), particularly in patients with decreased immunological responsiveness $(2,3)$.

Among JCV isolates from the brain of PML patients, there is a remarkable variation in the structures of the regulatory regions of the genomes, although the structures of the other regions are apparently conserved (4-10). It has been proposed that the variation of PML-type isolates arose from an adaptation of JCV to growth in brain tissue $(5,6,10,11)$. In 1990 , we molecularly cloned JCV DNAs from the urine of healthy individuals and nonimmunosuppressed patients, and analyzed them for the structures of the regulatory regions (12). We found that the regulatory sequences of all cloned JCV DNAs were identical, except for a few nucleotide mismatches and that this regulatory sequence (designated archetype) could generate all the regulatory sequences of PML-type JCV isolates defined previously (12).

To further establish the relationship between JCV isolates of PML-type and archetype, we recently constructed a phylogenetic tree for $14 \mathrm{JCV}$ isolates in the world (seven archetypes and seven PML-types) from DNA sequence data on the VP1 (major capsid protein) gene (13). According to the phylogenetic tree, the 14 isolates divided into types $A$ and $B$, each of which contained archetypal and PMLtype isolates. Each type was further divideded into several groups, most of which contained archetypes and PML-types. We conclude that PML-type isolates are polyphyletic in their origin and do not constitute a unique lineage.

In that phylogenetic study, however, some archetypal JCV isolates (isolates C1 and CY) were not correlated with any PML-type isolate (13). Because the number of PML-type isolates compared was relatively small, we might have 
missed PML-type counterparts of $\mathrm{C} 1$ and CY. Alternatively, it was conceivable that some archetypal strains intrinsically could not generate PML-type variants. In this study, we examined this issue by constructing a phylogenetic tree for eight Japanese JCV isolates, five PML-type isolates obtained in this and previous studies and three representative archetypal isolates.

\section{MATERIALS AND METHODS}

PML brain tissue: The PML patients studied are shown in Table I. The clinical diagnosis was confirmed by characteristic histophathology and by an immunohistochemical assay with anti-capsid antibody (14).

Extraction of DNA from tissue: The brain tissue obtained at autopsy was minced with scissors and digested with $50 \mu \mathrm{g} / \mathrm{ml}$ of proteinase $\mathrm{K}$ (Merck, Rahway, $\mathrm{NJ}$ ) in the presence of $0.5 \%$ sodium dodecyl sulfate at $56 \mathrm{C} \mathrm{for} 1 \mathrm{hr}$. The digest was extracted once with phenol and once with chloroform-isoamyl alcohol (24/1). DNA was recovered by ethanol precipitation and dissolved in a small volume of buffer $\mathrm{E}$ ( $2 \mathrm{mM}$ Tris-HCl, pH 7.6, $2 \mathrm{mM} \mathrm{NaCl}$, and $0.2 \mathrm{mM}$ EDTA).

Cloning of JCV DNA: JCV DNA from brain tissue was enriched by sizefractionation on an agarose gel and digested with BamHI which cleaves JCV DNA at a single site. The BamHI-digested tissue DNA was ligated with BamHIand bacterial-alkaline-phosphatase-digested pUC19. The ligated DNAs were used to transform Escherichia coli $\mathrm{DH} 5 \alpha$ by high-voltage electroporation (15). Recombinant plasmids were selected by two rounds of colony hybridization (16) with 32P-labeled JCV DNA as the probe.

The origins of the JCV DNA clones that were previously established and studied here are as follows: PML-type isolates Tokyo-1 (9) and Sap-1 (17), archetypal isolates MY, CY, and YI (12).

Restriction analysis of viral DNA: Restriction enzymes were obtained from Toyobo Co. Ltd., Osaka, and samples were digested as recommended by the supplier. The digested DNAs were separated on a 0.6 to $1.8 \%$ horizontal agarose gel, depending upon the sizes of the fragments. As size references, the HindIII fragments of lambda phage DNA and the HinfI fragments of plasmid pUC19 were electrophoresed in parallel.

Sequencing: The regulatory regions were sequenced as follows: A HindIIINcoI fragment containing a region from the origin of DNA replication to the start site of the late leader protein (agnoprotein) was inserted into M13 mp18 and mp19 between the SmaI and HindIII sites. Single-stranded DNAs purified from recombinant phages were sequenced by chain termination (18). Sequencing was carried out with the overlapping clones representing both strands. 
The VP1 genes [1065 nucleotides (nt) in size] were sequenced as previously described (13). The sequences of the VP1 genes of Aic-1a, Tky-1, Tky-2a, and YI were determined in this study. The published sequence data for Tokyo-1, Sap-1, MY and CY (13) were used.

The nucleotide sequence data reported in this paper will appear in the GSDB, DDBJ, EMBL, and NCBI nucleotide sequence databases with the following accession numbers: D26584 (Aic-1a, regulatory region), D26585 (Aic-1b, regulatory region), D26586 (Tky-1, regulatory region), D26587 (Tky-2a, regulatory region), D26588 (Tky-2b, regulatory region), D26589 (Aic-1a, VP1 gene), D26590 (Tky-1, VP1 gene), D26591 (Tky-2a, VP1 gene), D26592 (YI, VP1 gene).

Phylogenetic tree: VP1 sequences were compared among all pairs of isolates and nucleotide difference scores were transformed into a matrix. This was then used to construct an evolutionary tree by the unweighted pair-group method with arithmetic averages (13).

\section{RESULTS}

\section{Cloning of JCV DNAs in the Brains of 3 PML Patients}

Eight to 19 clones were obtained from the patients and all of them were analyzed with SstI, an enzyme which cleaves JCV DNA at multiple sites including

Fig. 1. Structures of the regulatory regions of JCV DNA clones obtained in this study. At the top is shown the regulatory sequence of a typical archetypal isolate (MY) in Japan. Below the MY sequences, the sequences of various clones determined in this study are shown. Dashes denote nucleotides identical with those in the MY sequence. Gaps denote deletions relative to the MY sequence. On reading from left to right, when a repeat is encountered, the linear representation is displaced to the line below and to a position corresponding to the sequences of the archetype. Oblique lines indicate points from or to which the linear representation is shifted. Some features are indicated by their similarity to the sequence of the isolate Mad-1TC (11). Alternative nucleotides found in another typical isolate in Japan (CY) are indicated below the MY sequence. An SstI cleavage site is indicated above the MY sequence. Domains A and B are sequences duplicated and deleted in most PML-type isolates, respectively (13). The nucleotide numbering system is that of Frisque et al (11). Abbreviations; ori: origin of DNA replication, TATA: TATA sequence, LP1: the start site of late leader protein (11). 


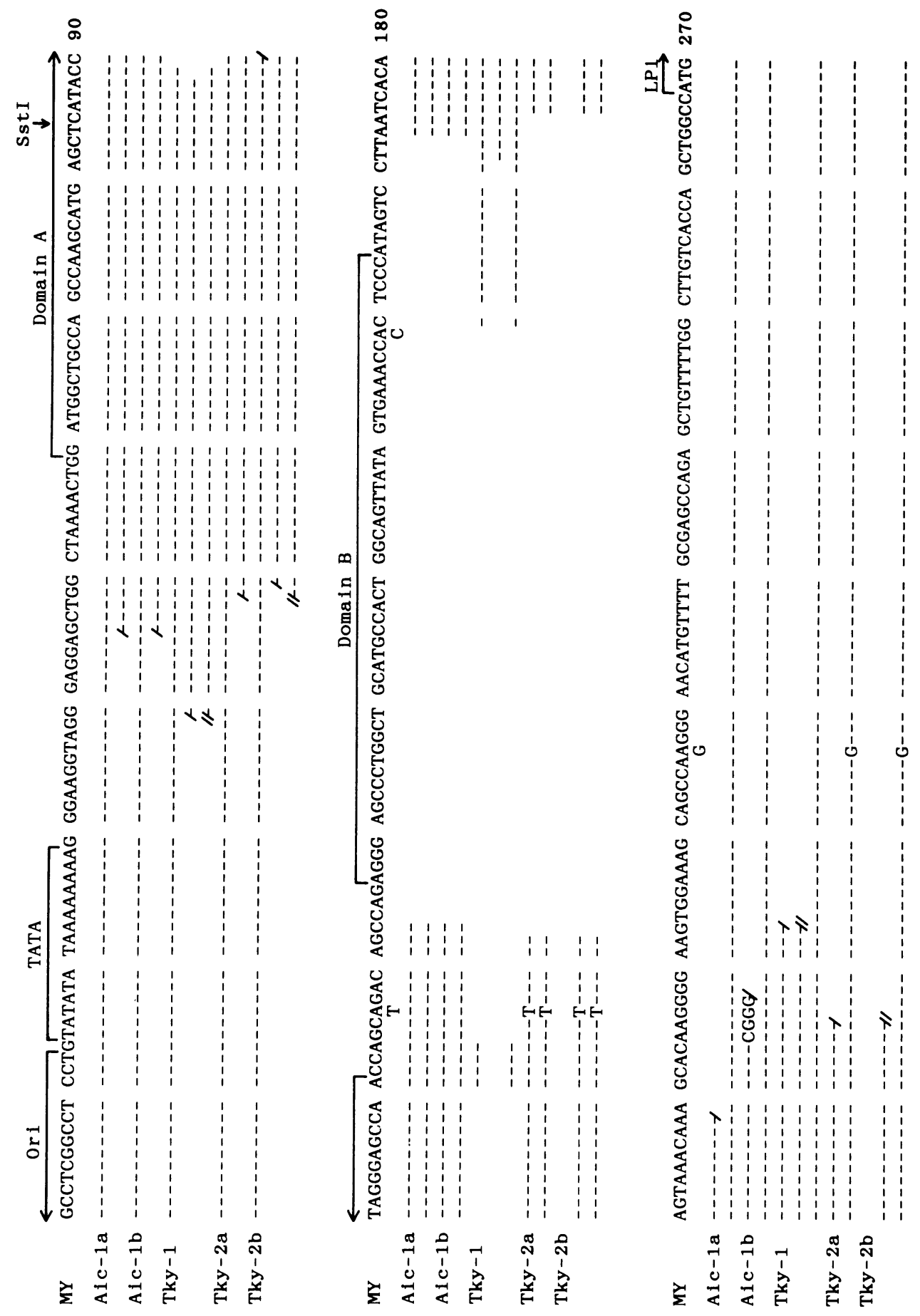


Table I. Cloning of JCV DNA from the brains of three PML patients

\begin{tabular}{|c|c|c|c|c|}
\hline \multirow[t]{2}{*}{ Patienta } & \multirow{2}{*}{$\begin{array}{l}\text { Underlying } \\
\text { disease }\end{array}$} & \multicolumn{3}{|c|}{$\begin{array}{l}\text { Number of clones } \\
\text { obtainedb }\end{array}$} \\
\hline & & & jor clone & minor clone \\
\hline $1(33, M)$ & Adult $\mathrm{T}$ cell leukemia & 8 & (Aic-1a) & 1 (Aic-1b) \\
\hline $2(44, F)$ & $\begin{array}{l}\text { Acquired immuno- } \\
\text { deficiency syndrome }\end{array}$ & 19 & (Tky-1) & 0 \\
\hline $3(55, M)$ & $\begin{array}{l}\text { Systemic lupus } \\
\text { erythematosus }\end{array}$ & 7 & (Tky-2a) & 1 (Tky-2b) \\
\hline
\end{tabular}

aAge (year) and gender are indicated in parentheses.

bNames of clones are indicated in parentheses.

one within the regulatory region (the location of the SstI site within the regulatory region is shown in Fig. 1). The SstI cleavage site within the regulatory regions was reiterated in all clones (data not shown), indicating the presence of repeated sequences. Furthermore, the restriction analysis revealed the presence of minor clones carrying regulatory regions that deviated slightly from those of major clones. We designated major and minor clones as shown in Table I.

\section{Structure of the Regulatory Regions of Cloned JCV DNAs}

We sequenced the regulatory regions of cloned JCV DNAs. Two to three clones were sequenced for each major species, while one was sequenced for each minor species. These sequences are shown in Fig. 1, in which the regulatory sequence of MY is shown at the top. Various sequences determined in this study are shown below the MY sequence. All clones analyzed contained reiterations and deletions in reference to the archetypal sequence. Two clones from patient 2 (Tky-1) and patient 3 (Tky-2b) carried triplicated sequences, while the others had duplications. These structural features of the current JCV DNAs suggest that they were generated from archetypal strains by sequence rearrangement in the regulatory region. 
We previously showed that the regulatory regions of most PML-type isolates share two structural features: duplication of a 42-nt sequence named domain A and deletion of a 48-nt sequence named domain $B$ (13). Clones from two patients (Aic-1a, -1b, Tky-1a, -b) carried these features. However, one clone (Tky-1) had a regulatory region that slightly deviated from the common structure: it had a triplication rather than duplication and the repeated sequences were 12 or 13-nt shorter than domain A. Similar triplicated sequences have recently been detected in JCVs from PML brain (19).

\section{Phylogeny}

We compared the nucleotide sequences of a 1065-nt region encoding VP1 in eight Japanese JCV isolates, five PML-types obtained in this and previous studies and three representative archetypes (CY, MY, and YI) in Japan. In Table II, only those nucleotides at the positions of variations are shown. In total, $21 \mathrm{nu}-$ cleotide changes were detected at 15 positions. Of the 21 nucleotide differences, six (19\%) caused amino acid substitutions in the VP1 gene.

From the data given in Table II, the numbers of nucleotide differences were calculated for each pairwise comparison among the eight isolates. By the unweighted pair-group method with arithmetic averages (13), an evolutionary tree was constructed based upon the observed nucleotide differences (Fig. 2). According to this phylogenetic tree, the eight isolates were divided into two major groups which were named subtypes MY and CY after the representative archetypal isolates. Four PML-type isolates belonged to subtype MY, and one (Tky-2a) to subtype CY. Isolates belonging to subtype MY were further divided into two groups, one containing archetype YI and PML-type Aic-1a and the other containing archetype MY and 3 PML-types (Tky-1, Sap-1, and Tky-1). 


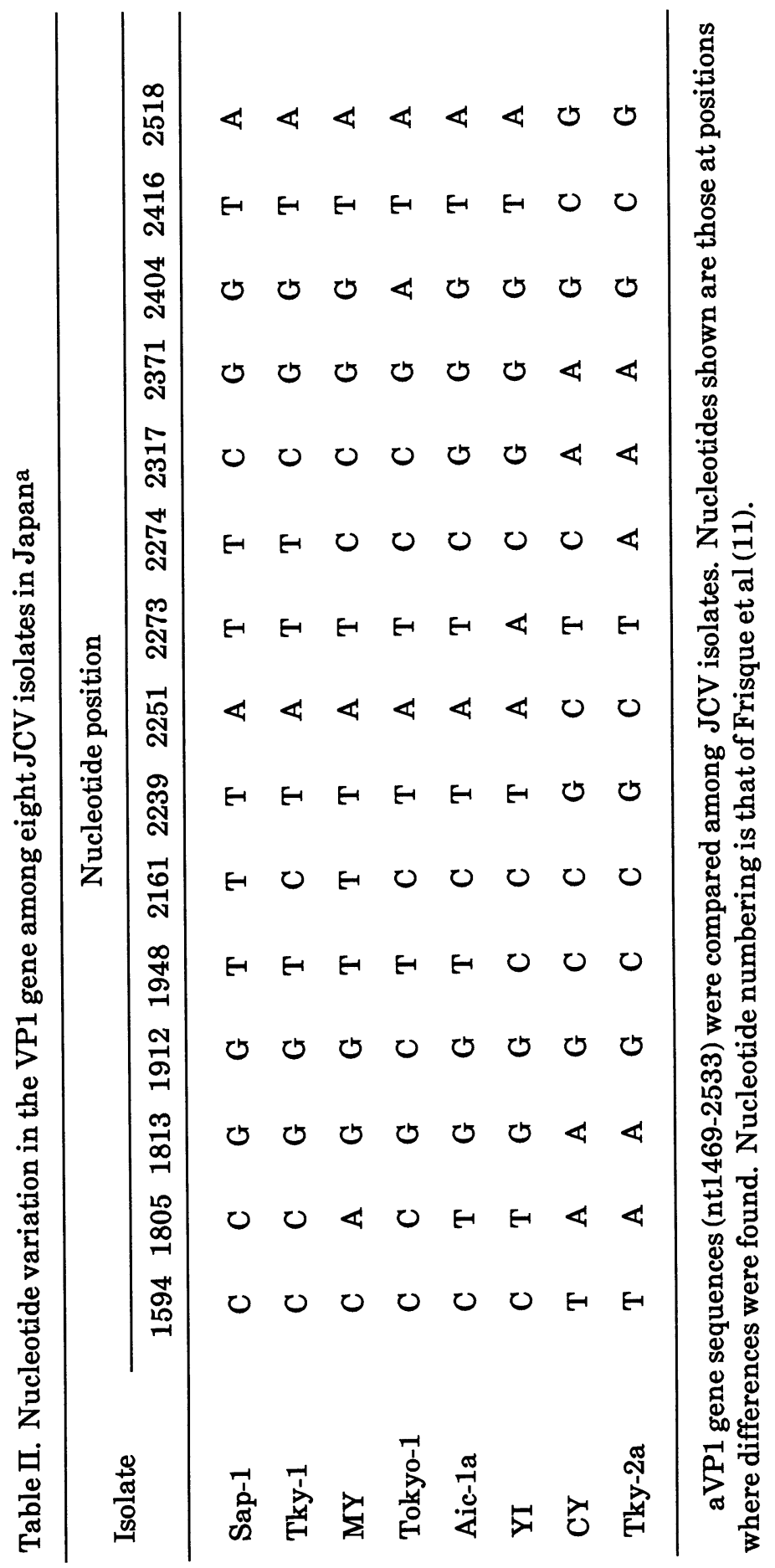




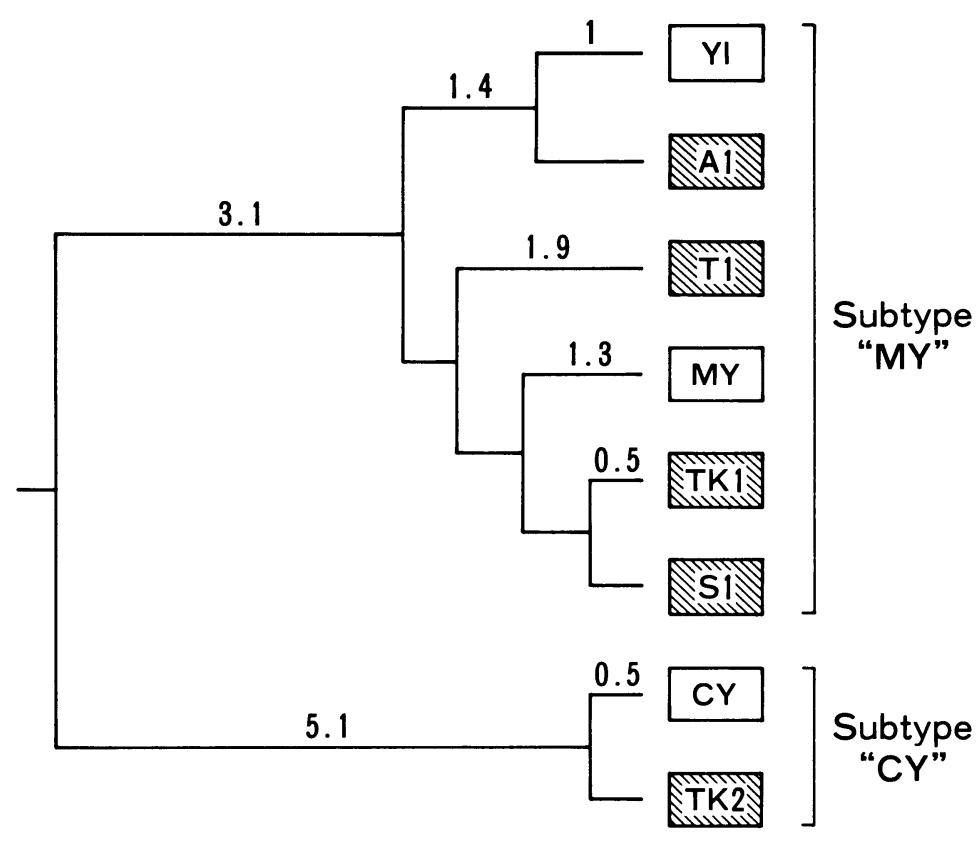

Archetype PML type

Fig. 2. An evolutionary tree relating eight JCV isolates in Japan. From the nucelotide differences calculated from Table II, an evolutionary tree was constructed by the unweighted pair-group method with arithmetic averages (13). Numbers indicate branch lengths shown in nt. A1: (Aic-1), T1: (Tokyo-1), TK1: (Tky-1), S1: (Sap-1), TK2: (Tky-2a).

\section{DISCUSSION}

In molecular phylogenetic analyses, one should not use unstable DNA sequences such as the JCV regulatory region which may occasionally rearrange in the course of persistence in hosts $(20,21)$. Therefore, we used the VP1-coding region as a marker in our phylogenetic study (13) as well as in this study. In our previous phylogenetic analysis, we correlated five PML-type isolates in the Unit- 
ed States with archetypal isolates in Europe and two PML-type isolates in Japan with an archetypal isolate in Japan (13). In a similar phylogenetic analysis, we correlated three new PML-type isolates in Japan with archetypal isolates: PMLtype Tky-1 and archetype MY; PML-type Aic-1a and archetype YI; and PML-type TK2 and archetype CY. Therefore, it is likely that any PML-type JCV isolate can be phylogenetically correlated with an archetypal isolate. Furthermore, this study suggests that any archetypal strain can intrinsically generate a PML-type JCV variant.

We previously showed that rearrangements of the archetypal regulatory sequence could generate all the regulatory sequences of PML-type JCV isolates defined at that time (12). This finding has been confirmed by subsequent molecular cloning of the PML-type isolates Sap-1 (17), NY-1A and -1B (22), as well as those in the current study. All of these PML-type regulatory regions contained reiteration and deletion in reference to the archetypal sequence (in addition, NY-1A carried an insertion of a segment within the T-antigen gene). Furthermore, Ault and Stoner (1993) recently analyzed JCV regulatory regions that were amplified by polymerase chain reaction from the brain of $11 \mathrm{PML}$ patients, and concluded that the rearranged regulatory regions were derived from the archetypal sequence. This ancestral relationship between archetypal and PML-type regulatory regions, together with the phylogenetic correlation between some PML-type isolates and some archetypal isolates suggest that PML-type JCVs were generated from archetypal JCVs during persistence in the hosts.

PML develops in various immunocompromised patients. These include patients with such underlying diseases as decrease their immunological capacity and those who are immunosuppressed therapeutically or after organ transplantation. JCV DNAs in the brains derived from various PML patients were found, without exception, to contain rearranged regulatory sequences that must have been generated from the archetypal sequence by deletions and amplifications $(12,17,19,22)$. This and previous studies $(19,22)$ have shown that this is also true for JCV DNAs in the PML brains of AIDS patients. Since it has been reported that incidence of PML is much higher in AIDS patients than in other PML risk groups (3), it should prove of interest to study how often rearrangement of JCV regulatory sequence occurs in AIDS patients. 


\section{ACKNOWLEDGEMENTS}

We thank Mr. Yuji Kasaoka, for his help in molecular cloning, and Dr. Yoshiyuki Nagai, Institute of Medical Science, University of Tokyo, for his helpful suggestions. This work was supported in part by a grant from the Japan Health Sciences Foundation.

\section{REFERENCES}

1. Padgett, B. L. and Walker, D. L. (1976): New human papovaviruses. Prog. Med. Virol., 22, 1-35.

2. Walker, D. L. (1985): Progressive multifocal leukoencephalopathy. p. 503524. In P. J. Vinken, G. W. Bruyn, H. L. Klawans and J. C. Koetsier (eds.), Handbook of clinical neurology 47. Revised series 3, Demyelinating diseases. Elsevier Science Publishers, Amsterdam.

3. Berger, J. R., Kaszovitz, B., Donovan Post, M. J. and Dickinson, G. (1987): Progressive multifocal leukoencephalopathy associated with human immunodeficiency virus infection. Ann. Intern. Med., 107, 78-87.

4. Rentier-Delrue, F., Lubiniecki, A. and Howley, P. M. (1981): Analysis of JC virus DNA purified directly from human progressive multifocal leukoencephalopathy brains. J. Virol., 38, 761-769.

5. Grinnell, B. W., Padgett, B. L. and Walker, D. L. (1983): Comparison of infectious JC virus DNAs cloned from human brain. J. Virol., 45, 299-308.

6. Dörries, K. (1984): Progressive multifocal leucoencephalopathy: analysis of JC virus DNA from brain and kidney tissue. Virus Res., 1, 25-38.

7. Martin, J. D. and Foster, G. C. (1984): Multiple JC virus genomes from one patient. J. Gen. Virol., 65, 1405-1411.

8. Martin, J. D., King, D. M., Slauch, J. M. and Frisque, R. J. (1985): Differences in regulatory sequences of naturally occurring $\mathrm{JC}$ virus variants. $\mathrm{J}$. Virol., 53, 306-311.

9. Matsuda, M., Jona, M., Yasui, K. and Nagashima, K. (1987): Genetic characterization of JC virus Tokyo-1 strain, a variant oncogenic in rodents. Virus Res., 7, 159-168.

10. Loeber, G. and Dörries, K. (1988): DNA rearrangement in organ-specific variants of polymavirus JC strain GS. J. Virol., 62, 1730-1735.

11. Frisque, R. J., Bream, G. L. and Cannella, M. T. (1984): Human polyomavirus JC virus genome. J. Virol., 51, 458-469.

12. Yogo, Y., Kitamura, T., Sugimoto, C., Ueki, T., Aso, Y., Hara, K. and Taguchi, F. (1990): Isolation of a possible archetypal JC virus DNA sequence from nonimmunocompromised individuals. J. Virol., 64, 3139-3143. 
13. Iida, T., Kitamura, T., Guo, J., Taguchi, F., Aso, Y., Nagashima, K. and Yogo, Y. (1993): Origin of JC polyomavirus variants associated with progressive multifocal leukoencephalopathy. Proc. Natl. Acad. Sci. USA, 90, 5062-5065.

14. Mori, M., Kurata, H., Tajima, M. and Shimada, H. (1991): JC virus detection by in situ hybridization in brain tissue from elderly patients. Ann. Neurol., 29, 428-432.

15. Dower, W. J., Miller, J. F. and Ragsdale, C. W. (1988): High efficiency transformation of E. coli by high voltage electroporation. Nucleic Acid Res., $16,6127-6145$.

16. Sambrook, J., Fritsch, E. F. and Maniatis, T. (1989): Molecular cloning. A laboratory manual. 2nd ed., Book 1. 6. 7. Cold Spring Harbor Laboratory Press, Cold Spring Harbor.

17. Takahashi, H., Yogo, Y., Furuta, Y., Takada, A., Irie, T., Kasai, M., Sano, K., Fujioka, Y. and Nagashima, K. (1992): Molecular characterization of a JC virus (Sap-1) clone derived from a cerebellar form of progressive multifocal leukoencephalopathy. Acta Neuropathol., 83, 105-112.

18. Sanger, F., Nicklen, S. and Coulson, A. R. (1977): DNA sequencing with chain-terminating inhibitors. Proc. Natl. Acad. Sci. USA, 74, 5463-5467.

19. Ault, G. S. and Stoner, G. L. (1993): Human polyomavirus JC promoter / enhancer rearrangement patterns from progressive multifocal leukoencephalopathy brain are unique derivatives of a single archetypal structure. J. Gen. Virol., 74, 1499-1507.

20. Yogo, Y., Kitamura, T., Sugimoto, C., Hara, K., Iida, T., Taguchi , F., Tajima, A., Kawabe, K. and Aso, Y. (1991): Sequence rearrangement in JC virus DNAs molecularly cloned from immunosuppressed renal transplant patients. J. Virol., 65, 2422-2428.

21. Kitamura, T., Satoh, K., Tominaga, T., Tabuchi, F., Tajima, A., Suzuki, K., Aso, Y. and Yogo, Y. (1994): Alteration in the JC polyomavirus genome is enhanced in immunosuppressed renal transplant patients. Virology, 198, 341-345.

22. Yogo, Y., Guo, J., Iida, T., Satoh, K. Taguchi, F., Takahashi, H., Hall, W. W. and Nagashima, K. (1994): Occurrence of multiple JC virus variants with distinctive regulatory sequences in the brain of a single patient with progressive multifocal leukoencephalopathy. Virus Genes, 8, 99-105. 